\title{
Recent findings of mosses from Orthotrichaceae family (Bryophyta) in the Czech part of the Western Carpathians. Part 1. The Moravskoslezské Beskydy Mts and its foothills
}

Vítězslav Plášek

Recent findings of mosses from Orthotrichaceae family (Bryophyta) in the Czech part of the Western Carpathians. Part 1. The Moravskoslezské Beskydy Mts and its foothill. - Čas. Slez. Muz. Opava (A), 60: 268-283, 2011.

Abstract: Recent distribution of mosses within Orthotrichaceae family in Moravskoslezské Beskydy Mts and its foothill is done. Particularly interesting findings are briefly commented. Among others, findings of the threatened species, e.g. Orthotrichum patens, Zygodon rupestris, are presented.

Keywords: Orthotrichum, Ulota, Zygodon, epiphytic bryophytes, Western Carpathians, Czech Republic

\section{Introduction}

During the last fifteen years an intensive bryological research in the Western Carpathians mountain ranges was carried out. The field survey was focused mainly on epiphytic bryophytes within Orthotrichaceae family. The bryophytes growing on the bark of tree were more frequented there before masive increasing of industrialization in the region in 1950's. Owning to worseness of air quality the abundance of their populations was declined and the species became rare and threatened there. Since 1990's the air quality has improved and that is why the epiphytic mosses have been recolonizing the former habitats. The aim of the first part of the series is to present the current state distribution of the mosses in Moravskoslezské Beskydy Mts and its foothills.

\section{Material and methods}

During 1997-2011 the material was collected (using standard methods) in Moravskoslezské Beskydy Mts and its foothills by autor together with the Bachelor's and Master's students of University of Ostrava. Over 6500 herbarium specimens have been collected on the study area. Ecological characteristics about host specificity, presence of sporophytes or gemmae were notes.

\section{Results}

For better orientation, the localities situated close to each other are arranged together into one section which is marked by name of major geographic location (e.g. town, Mt). These major location are arranged alphabecically.

\section{List of findings}

\author{
Nyholmiella obtusifolia (Brid.) Holmen et Warncke
}

\section{Bílá village}

$1.3-1.5 \mathrm{~km}$ NE of Bílá village, valley of Černá Ostravice stream, $552 \mathrm{~m}$ a.s.1., bark of Tilia platyphyllos \& Salix caprea, leg. Pasečná 4.VII.2006, det. Plášek (OP).

1.6 km NW of Bílá village, loc. "Javořinka", 750 m a.s.l., bark of Malus sp., leg. Plášek 18.VI.1998 (OP).

$2 \mathrm{~km}$ NE of Bílá village \& $6.8 \mathrm{~km}$ SW of loc. "Bílý Kř́ž", middle part of Černá Ostravice stream valley, 576 m a.s.l., bark of tree Tilia platyphyllos, leg. Pasečná 4.VII.2006, det. Plášek (OP).

W edge of Bílá village, part Zámeček, 528 m a.s.l., bark of Sorbus aucuparia \& Malus sp., leg. Plášek 9.XII.2006 (OP).

Bílý Křriž

2 km NNE of Sulov hill, Byčinec Reserve, 700 m a.s.l., bark of Sorbus aucuparia, leg. Plášek 9.VI.2009 (OP).

Bukovec

1 km NE of Bukovec village, apple orchard, 465 m a.s.l., bark of Pyrus sp., leg. Plášek 23.VII.2004 (OP).

Bystřice nad Olší

E edge of Bystřice nad Olší village, 450 m a.s.l., on a concrete bridge, leg. Plášek 29.V.2001 (OP).

Čeladná

3-3.5 km S of Čeladná village, loc. "Hamry", alley of old deciduos trees, $550 \mathrm{~m}$ a.s.1., bark of Fraxinus excelsior, leg. Plášek \& Stebel 25.IX.2005 (OP, SOSN).

7.5-8.5 km S of Čeladná village, loc. "Pod kaštany", along a public road, 596-610 m a.s.l., bark of Aesculus hippocastanum, leg. Plášek 25.IX.2005 (OP). 
$1.2 \mathrm{~km}$ NW of Čeladná village, SE slope of Ondřejník hill, $2 \mathrm{~km} \mathrm{SE}$ of the summit of the hill, $720 \mathrm{~m}$ a.s.1., bark of Quercus robur, leg. Brus 1.XI.2007, det. Plášek (OP).

\section{Dobrá}

$3 \mathrm{~km}$ E of Dobrá town, $1.5 \mathrm{~km} \mathrm{SW}$ of Vojkovice village, along public road, $343 \mathrm{~m}$ a.s.l., bark of Malus sp., leg. Plášek 23.VII.2004 (OP).

\section{Dolní Lomná}

Dolní Lomná village, centre of the village, near "Pod Akáty" pub, 466 m a.s.l., bark of Populus sp., leg. Plášek 28.VII.2005 (OP).

\section{Horní Bečva}

Horní Bečva village, 2.3 km N of Opálený settlement, valley of Mečůvka stream, $635 \mathrm{~m}$ a.s.l., bark of Malus sp., leg. Štefúnová 20.IX.2007, det. Plášek (OP).

\section{Horní Lomná}

S edge of Horní Lomná village, along a touristic path (yellow sign), 533 m a.s.1., bark of Salix fragilis, leg. Plášek 5.XI.2005 (OP).

Horní Lomná village, centre of the village, along public road, $600 \mathrm{~m}$ a.s.l., bark of Fraxinus excelsior, leg. Plášek 24.VII.2000 (OP).

\section{Mionší}

Top of Menší vrch hill, Mionší Reserve, loc. "Velká polana" meadow, 880 m a.s.l., bark of Fagus sylvatica, leg. Plášek 29.VII.2005 (OP)

\section{Morávka}

1 km NE of Morávka village, SE slope of Malý Lipový hill, 600 m a.s.l., bark of Malus sp., Sambucus nigra \& Pyrus sp., leg. Nociarová 29.VII.2006, det. Plášek (OP).

$1.8 \mathrm{~km}$ WNW of Morávka village, middle part of Vlašský potok stream valley, in a garden, $500 \mathrm{~m}$ a.s.l., bark of Malus sp., leg. Nociarová 20.VII.2006, det. Plášek (OP).

$2.1 \mathrm{~km}$ NE of Morávka village, SW edge of Velký Lipový settlement, right tributary of Velký Lipový stream, $550 \mathrm{~m}$ a.s.l., bark of Salix sp., Malus sp. \& Fraxinus excelsior, leg. Nociarová 25.VII.2006, det. Plášek (OP).

$2.8 \mathrm{NW}$ of the edge of Morávka village, between Morávka and Pražmo villages, valley of Morávka stream, in a garden, 430 m a.s.1., bark of Malus sp., Tilia cordata \& Fraxinus excelsior, leg. Nociarová 24.VII.2006, det. Plášek (OP).

\section{Mořkov}

$1.3-2.5 \mathrm{~km}$ SE of Mořkov village, near a touristic path, 480-500 m a.s.l., bark of Salix sp., leg. Hradilová 12.VIII.2007, det. Plášek (OP).

$2.7 \mathrm{~km}$ SSE of Hodslavice village \& $2.3 \mathrm{~km} \mathrm{SW}$ of Mořkov village, loc. "Mořkovský les" forest, $650 \mathrm{~m}$ a.s.l., bark of Ulmus glabra, leg. Hradilová, 20.VIII.2007, Plášek (OP).

\section{Nýdek}

Nýdek village, between loc. "Guty" and "Gora", valley of Horský potok stream, 510 m a.s.1., bark of Acer pseudoplatanus, leg. Plášek 30.IX.1999 (OP).

Nýdek village, loc. "Guty", valley of Horský potok stream, 500 m a.s.l., leg. Plášek 30.IX.1999 (OP).

Nýdek village, valley of Hluchová stream, 460 m a.s.1., bark of Acer pseudoplatanus, leg. Kučera 30.IX.1999, teste Plášek (priv. coll. Kučera).

Nýdek village, near a chaple, 480 m a.s.1., bark of Acer pseudoplatanus, leg. Plášek 1.X.1999 \&18.X.1999 (OP).

Ostravice

1.3-1.5 km NE of Bílá village, valley of Černá Ostravice stream, 533-552 m a.s.1., bark of Salix caprea, Alnus incana \& Tilia platyphyllos, leg. Pasečná 4.VII.2006, det. Plášek (OP).

2 km SSE of Ostravice village, valley of Mazák, 450 m a.s.l., bark of Acer pseudoplatanus, leg. Plášek 12.V.2005 (OP). Plants with sporogones!

SW edge of Ostravice village, $460 \mathrm{~m}$ a.s.1., bark of Malus sp., leg. Sovík 3.VIII.2004, det. Plášek (OP).

$4 \mathrm{~km} \mathrm{SW}$ of Ostravice village, SE slope of Smrk Mt., 1100 m a.s.1., bark of Acer pseudoplatanus, leg. Plášek 29.IX.2003 (OP).

Pustevny

1.5 km WNW of Pustevny Mt., under Velká sjezdovka ski slope, $850 \mathrm{~m}$ a.s.l., bark of Acer pseudoplatanus, leg. Plášek 10.II.2007 (OP).

Rožnov p.R.

Rožnov pod Radhoštěm town, Skanzen open-air museum, 390 m a.s.l., bark of Fraxinus excelsior, leg. Plášek 11.II.2007 (OP).

Salajka

290 m NE of Bumbálka border settlement, edge of Salajka reserve, 862 m a.s.l., bark of Fraxinus excelsior, leg. Plášek 9.XII.2006 (OP).

\section{Staré Hamry}

$300 \mathrm{~m}$ NE of Staré Hamry settlement, $1 \mathrm{~km} \mathrm{~S}$ of Príslop hill, valley of Černá Ostravice stream, 517 m a.s.l., bark of Salix caprea, Malus sp. \& Tilia cordata, leg. Plášek 12.IX.2006 (OP).

$500 \mathrm{~m} \mathrm{~W}$ of Staré Hamry settlement, $1.2 \mathrm{~km}$ SSW of Príslop hill, valley of Černá Ostravice stream, $501 \mathrm{~m}$ a.s.l., bark of Fraxinus excelsior, leg. Plášek 12.IX.2006 (OP).

$2.5 \mathrm{~km} \mathrm{~W}$ of Staré Hamry village, $500 \mathrm{~m}$ SSW of Hutě village, along yellow touristic path, $538 \mathrm{~m}$ a.s.1., bark of Salix purpurea, leg. Sovík 15.IV.2005, det. Plášek (OP).

Staré Hamry settlement, 505 m a.s.1., bark of Salix fragilis, leg. Plášek 12.IX.2006 (OP).

2.5 km NE od Staré Hamry village, Podgrúň Reserve, 800 m a.s.1., bark of Salix sp., leg. Plášek 9.VIII.2009 (OP). 


\section{Veřovice}

$1 \mathrm{~km}$ SSE of Veřovice village, loc. "Padolí", valley of Jičínka stream, $570 \mathrm{~m}$ a.s.l., bark of Malus sp., leg. Hradilová 4.XI.2007, det. Plášek (OP).

\section{O. affine Schrad. ex Brid.}

\section{Bílá village}

1.2-1.3 km NE of Bílá village, valley of Černá Ostravice stream, 524-604 m a.s.1., bark of Salix caprea, Aesculus hippocastanum, Sorbus aucuparia \& Tilia platyphyllos, leg. Pasečná 4.VII.2006, det. Plášek (OP).

2.4 km E of Bílá village, middle part of Chladná voda stream valley, $691 \mathrm{~m}$ a.s.l., bark of Fagus sylvatica, leg. Pasečná 3.VII.2007, det. Plášek, V. (OP).

4.7 km NE of Bílá village, valley of Černá Ostravice stream, $620 \mathrm{~m}$ a.s.l., bark of Populus tremula, leg. Pasečná 11.VII.2006, det. Plášek (OP).

3.5 km SW of Bílá village, Mezivodí settlement, 604 m a.s.l., bark of Salix caprea, leg. Plášek 9.XII.2006 (OP).

W edge of Bílá village, part Zámeček, 555 m a.s.l., bark of Acer pseudoplatanus \& Tilia cordata, leg. Plášek 9.XII.2006 (OP).

Bílý Kříž

loc. Bílý Kř́žž, ca. 150 m NW of Czech-Slovak border line \& 500 m SSW of Sulov hill, 849 m a.s.1., bark of Salix caprea, leg. Plášek 12.IX.2006 (OP).

2 km NNE of Sulov hill, Byčinec Reserve, 700 m a.s.l., bark of Sorbus aucuparia, leg. Plášek 9.VI.2009 (OP).

Dolní Lomná

Centre of Dolní Lomná village, near "Pod Akáty" pub, 466 m a.s.1., bark of Populus sp., leg. Plášek 28.VII.2005 (OP).

Čeladná

3 - $3.5 \mathrm{~km} \mathrm{~S}$ of Čeladná village, loc. "Hamry", alley of old deciduous trees, $496 \mathrm{~m}$ a.s.1., bark of Acer pseudoplatanus \& Fraxinus excelsior, leg. Plášek 25.IX.2005 (OP).

Frenštát p. R.

3.2 km SW of Frenštát pod Radhoštěm town, the summit of Velký Javorník hill, 904 m a.s.1., bark of Salix caprea, leg. Hradilová 20.IX.2007, det. Plášek (OP).

$2.8 \mathrm{~km}$ SW of Frenštát pod Radhoštěm town, E slope of Velký Javorník hill, 820 m a.s.1., bark of Acer campestre, leg. Hradilová 20.IX.2007, det. Plášek (OP).

S edge of Trojanovice village, valley of Radhoštnice stream, near hotel "Gurmán", 560 m a.s.1., bark of Salix caprea, leg. Plášek 16.X.2008 (OP).

Horní Bečva

1.1 km ENE of Opálený settlement, $1 \mathrm{~km} \mathrm{SW}$ of Kudlačena reserve, $655 \mathrm{~m}$ a.s.l., bark of Salix caprea, leg. Štefúnová 20.IX.2007, det. Plášek (OP).

2 km NNE of Horní Bečva village, valley of Kobylská stream, Bukoviny settlement, $607 \mathrm{~m}$ a.s.1., bark of Fraxinus excelsior, leg. Štefúnová 14.IX.2007, det. Plášek (OP).

510 m NE of Horní Bečva village, 911 m SW of Kobylská hill, 633 m a.s.1., bark of Acer pseudoplatanus, leg. Štefúnová 14.IX.2007, det. Plášek (OP).

\section{Horní Lomná}

S edge of Horní Lomná village, along a touristic path (yellow sign), $531 \mathrm{~m}$ a.s.l., bark of Acer pseudoplatanus, Fraxinus excelsior \& Salix sp., leg. Plášek 5.XI.2005 (OP).

Centre of the Horní Lomná village, along public road, 600 m a.s.l., bark of Fraxinus excelsior \& Salix sp., leg. Plášek 24.VII.2000 (OP).

Lysá hora

$400 \mathrm{~m} \mathrm{SW}$ of the summit of Lysá hora Mt., a beech forest, $1050 \mathrm{~m}$ a.s.1., bark of Fagus sylvatica, leg. Plášek 2.IX.2003 (OP).

Masarykovo údolí

Masarykovo údolí valley, 541-573 m a.s.l., bark of Salix caprea, Fraxinus excelsior, Acer pseudoplatanus \& Acer platanoides, leg. Pasečná 18.VIII.2008, det. Plášek (OP).

\section{Mionší}

Top of Menší vrch hill, Mionší Reserve, loc. "Velká polana" meadow, 880 m a.s.l., bark of Fagus sylvatica, leg. Plášek 29.VII.2005 (OP).

Morávka village

$1 \mathrm{~km}$ NE of Morávka village, SE slope of Malý Lipový hill, $600 \mathrm{~m}$ a.s.l., bark of Malus sp. \& Sambucus nigra, leg. Nociarová 29.VII.2006, det. Plášek (OP).

$1.7 \mathrm{~km} \mathrm{SW}$ of Morávka village, upper part of valley of Vlašský potok stream, $610 \mathrm{~m}$ a.s.l., bark of Acer platanoides \& Fraxinus excelsior, leg. Nociarová 20.VII.2006, det Plášek (OP).

$1.8 \mathrm{~km}$ WNW of Morávka village, middle part of valley of Vlašský potok stream, in a garden, $500 \mathrm{~m}$ a.s.l., bark of Malus sp., leg. Nociarová 20.VII.2006, det. Plášek (OP).

2.1 km NE of Morávka village, SW edge of Velký Lipový settlement, right tributary of Velký Lipový stream, $550 \mathrm{~m}$ a.s.1., bark of Pyrus sp., leg. Nociarová 25.VII.2006, det. Plášek (OP).

Between Morávka and Pražmo villages, valley of Morávka stream, $2.8 \mathrm{NW}$ of the edge of Morávka village, in a garden, bark of Malus sp., 430 m a.s.1., leg. Nociarová 24.VII.2006, det. Plášek (OP).

Mořkov village

1 km SE of Mořkov village, loc. "Pod Justýnem", 480 m a.s.1., bark of Acer pseudoplatanus, leg. Hradilová 20.VIII.2007, det. Plášek (OP). 
$2.7 \mathrm{~km}$ SSE of Hodslavice village \& $2.3 \mathrm{~km} \mathrm{SW}$ of Mořkov village, loc. Mořkovský les forest, $650 \mathrm{~m}$ a.s.1., bark of Ulmus glabra, leg. Hradilová 20.VIII.2007, det. Plášek (OP).

$8 \mathrm{~km}$ SE of Př́bor town, between Tichá and Lichnov villages, apple orchard, $331 \mathrm{~m}$ a.s.l., bark of Malus sp., leg. Plášek 30.VI.2004 (OP).

$1 \mathrm{~km} \mathrm{SSW}$ of edge of Hoslavice village \& $600 \mathrm{~m}$ SE of edge of Hostašovice village, loc. "Prameny Zrzávky I." Nature Monument, 392 m a.s.l., bark of Salix fragilis, leg. Plášek 30.IV.2004 (OP).

Nýdek

Nýdek village, near a chaple, 480 m a.s.1., bark of Acer pseudoplatanus, leg. Plášek \& Kučera 1.X.1999 (OP, priv. coll. Kučera).

Nýdek village, valley of Hluchová stream, 460 m a.s.1., leg. Novotný 1.X.1999 (BRNM);

$2 \mathrm{~km}$ E of Nýdek village, along touristic way towards Velká Čantoryje Mt, 489 m a.s.l., bark of Fraxinus excelsior, leg. Plášek 2.IX.2004 (OP).

\section{Ondřejník}

NE slope of Ondřejník hill, $1.2 \mathrm{~km} \mathrm{NE}$ of the summit of the hill, along a forest road, $662 \mathrm{~m}$ a.s.l., bark of Acer pseudoplatanus, leg. Brus 14.IX.2007, det. Plášek (OP).

W slope of Ondřejník hill, $400 \mathrm{~m} \mathrm{~W}$ of the summit of the hill, along a forest road, $690 \mathrm{~m}$ a.s.l., bark of Sambucus nigra, leg. Brus 10.X.2007, det. Plášek (OP).

\section{Ostravice}

2 km SSE of Ostravice village, valley of Mazák, 450 m a.s.l., bark of Acer pseudoplatanus \& Sambucus nigra, leg. Plášek 12.V.2005 (OP).

SW edge of Ostravice village, $460 \mathrm{~m}$ a.s.l., bark of Malus sp., leg. Sovík 3.VIII.2004, det. Plášek (OP).

NE edge of Ostravice village, 425 m a.s.l., bark of Salix caprea, leg. Sovík 3.VIII.2004, det. Plášek (OP).

Pustevny settlement

$3.4 \mathrm{~km} \mathrm{SE}$ of Pustevny settlement, $1.5 \mathrm{~km} \mathrm{SW}$ of Magurka Mt, $1011 \mathrm{~m}$ a.s.l., bark of Salix caprea, leg. Štefúnová 16.IX.2007, det. Plášek (OP).

$250 \mathrm{~m} \mathrm{~S}$ of Pustevny settlement, along a public road, 1002 m a.s.l., bark of Sorbus aucuparia, leg. Štefúnová 16.IX.2007, det. Plášek (OP).

2.8 km SE of Pustevny settlement, 1.4 km S of Čertův Mlýn Mt, 953 m a.s.l., bark of Salix caprea, leg. Štefúnová 16.IX.2007, det. Plášek (OP).

Rožnov p. R.

Rožnov pod Radhoštěm town, Skanzen open-air museum, 390 m a.s.l., bark of Fraxinus excelsior, leg. Plášek 11.II.2007 (OP).

\section{Staré Hamry}

$300 \mathrm{~m}$ NE of Staré Hamry settlement, 1 km S of Príslop hill, valley of Černá Ostravice stream, 517 m a.s.l., bark of Tilia cordata, leg. Plášek 12.IX.2006 (OP).

$2.5 \mathrm{~km} \mathrm{~W}$ of Staré Hamry village, $500 \mathrm{~m}$ SSW of Hutě village, along yellow touristic path, $538 \mathrm{~m}$ a.s.l., bark of Salix purpurea, leg. Sovík 15.IV.2005, det. Plášek (OP).

$3.5 \mathrm{~km}$ NE of Staré Hamry settlement, valley of Černá Ostravice stream, $1.2 \mathrm{~km}$ SE of Velký Lučný hill, $598 \mathrm{~m}$ a.s.l., bark of Salix caprea, leg. Plášek 12.IX.2006 (OP).

$690 \mathrm{~m}$ NE of Staré Hamry settlement, valley of Černá Ostravice stream, 950 m SE of Príslop hill, 550 m a.s.1., bark of Acer pseudoplatanus, leg. Plášek 12.IX.2006 (OP).

2.5 km NE od Staré Hamry village, Podgrúň Reserve, 800 m a.s.1., bark of Salix sp., leg. Plášek 9.VIII.2009 (OP).

\section{O. anomalum Hedw.}

\section{Bystř̌čka}

3 km E of Bystřička village, bank of water reservoir, 400 m a.s.l., on a stone, leg. Kašparová 4.XI.1999, teste Plášek (VM).

Horní Bečva

1.6 km N of Podlízaná settlement, 240 m SW of Kladnatá hill, 813 m a.s.l., bark of Salix caprea, leg. Štefúnová 20.IX.2007, det. Plášek (OP).

\section{Horní Lomná}

Horní Lomná village, 545 m a.s.l., a concrete wall, leg. Fajkusová 22.V.2005, det. Plášek (OP)

\section{Jablunkov}

Radvanov settlement, valley of Radvanov stream, 600 m a.s.l., on a wall, leg. Plášek 30.VIII.2000 (OP).

3 km NNE of Radvanov village, upper part of Radvanov stream valley, 600 m a.s.l., a concrete wall, leg. Plášek 30. VIII.2000 (OP).

Kunčice p. $O$.

NE slope of Ondřejník hill, $955 \mathrm{~m}-1.2 \mathrm{~km} \mathrm{NE}$ of the summit of the hill, along a forest road, 662-697 m a.s.1., bark of Acer pseudoplatanus, leg. Brus 14.IX.2007, det. Plášek (OP).

\section{Malenovice}

Malenovice village, a cementary in Borová hill, 500 m a.s.l., leg. Duda 4.VIII.1997 (priv. coll. Duda).

\section{Morávka}

$2.8 \mathrm{~km} \mathrm{NW}$ of the edge of Morávka village, between Morávka and Pražmo villages, valley of Morávka stream, in a garden, 430 m a.s.1., bark of Malus sp. \& Prunus sp., leg. Nociarová 24.VII.2006, det. Plášek (OP).

$2.1 \mathrm{~km}$ NE of Morávka village, SW edge of Velký Lipový settlement, right tributary of Velký Lipový stream, $550 \mathrm{~m}$ a.s.1., bark of Malus sp., leg. Nociarová 25.VII.2006, det. Plášek (OP). 
1 km NE of Morávka village, SE slope of Malý Lipový hill, 600 m a.s.1., bark of Malus sp., leg. Nociarová 29.VII.2006, det. Plášek (OP).

\section{Mořkov}

5 km ESE of Mořkov village, along red tourist path, 775 m a.s.l., bark of Acer pseudoplatanus, leg. Hradilová 6.X.2007, det. Plášek (OP).

$2.7 \mathrm{~km}$ SSE of Hodslavice village \& $2.3 \mathrm{~km}$ SW of Mořkov village, loc. "Mořkovský les" forest, $650 \mathrm{~m}$ a.s.l., bark of Ulmus glabra, leg. Hradilová, 20.VIII.2007, det. Plášek (OP).

\section{Ostravice}

NE edge of Ostravice village, near the bridge, 425 m a.s.1., bark of Salix caprea, leg. Sovík 3.VIII.2004, det. Plášek (OP).

2 km SSE of Ostravice village, valley of Mazák, 450 m a.s.l., bark of Acer pseudoplatanus leg. Plášek 12.V.2005 (OP).

\section{Pustevny}

$3.2 \mathrm{~km}$ SSE of Pustevny settlement, $2 \mathrm{~km}$ NE of Bácov village, along a public road, $594 \mathrm{~m}$ a.s.l., bark of Fraxi-nus excelsior, leg. Štefúnová 16.IX.2007, det. Plášek (OP).

Stará Ves n.o.

Stará Ves nad Ondřejnicí village, along a public road, 240 m a.s.l., bark of Malus sp., leg. Plášek 5.VIII.2005 (OP).

Staré Hamry

Staré Hamry village, in a garden, 550 m a.s.1., bark of a deciduous tree, leg. Duda 25.IX.2005, det. Plášek (priv. coll. Duda).

Životice u N.J.

Nový Jičín distr., Životice u Nového Jičína village, 380 m a.s.l., on a picrite rock, Plášek 17.VI.2002 (OP).

\section{O. cupulatum Hoffm. ex Brid.}

\section{Ostravice}

Ostravice village, a cementary, 400 m a.s.l., leg. Duda 14.VIII.1996, teste Plášek (priv. coll. Duda).

\section{O. diaphanum Schrad. ex Brid.}

Bílá

W edge of Bílá village, part Zámeček, 528 m a.s.l., bark of Sorbus aucuparia, leg. Plášek 9.XII.2006 (OP).

Bílý Kř́íž

2 km NNE of Sulov hill, Byčinec Reserve, 700 m a.s.1., bark of Sorbus aucuparia, leg. Plášek 9.VI.2009 (OP).

Frenštát p.R.

$2.8 \mathrm{~km} \mathrm{SW}$ of Frenštát pod Radhoštěm town, E slope of Velký Javorník hill, 820 m a.s.1., bark of Acer campestre, leg. Hradilová 20.IX.2007, det. Plášek (OP).

Hodslavice

$1 \mathrm{~km} \mathrm{SSW}$ of edge of Hodslavice village \& $600 \mathrm{~m}$ SE of edge of Hostašovice village, loc. "Prameny Zrzávky I." Nature Monument, 392 m a.s.l., bark of Salix fragilis, leg. Plášek 30.IV.2004 (OP).

\section{Horní Bečva}

Horní Bečva village, 360 m - 2.3 km N of Opálený settlement, valley of Mečůvka stream, 524-635 m a.s.1., bark of Malus sp. \& Acer pseudoplatanus, leg. Štefúnová 20.IX.2007, det Plášek (OP).

\section{Hrádek}

2 km NNW of Hrádek nad Olší village, valley of Kompařov stream, between Hrádek nad Olší village and V Pasekách settlement, 405 m a.s.l., bark of Malus sp., leg. Plášek 12.X.2001 (OP).

\section{Jablunkov}

$1 \mathrm{~km} \mathrm{NE}$ of Bukovec village, along public road, apple orchard, 465 m a.s.l., bark of Malus sp., leg. Plášek 23.VII.2004 (OP).

Morávka

$2.1 \mathrm{~km}$ NE of Morávka village, SW edge of Velký Lipový settlement, right tributary of Velký Lipový stream, in a garden, 550 m a.s.l., bark of Malus sp. \& Salix sp., leg. Nociarová 25.VII.2006, det. Plášek (OP).

2.7 km SE of Morávka village, upper part valley of Vlašský potok stream, edge of a forest, $785 \mathrm{~m}$ a.s.l., bark of Fraxinus excelsior, leg. Nociarová 24.VII.2006, det. Plášek (OP).

Between Morávka and Pražmo villages, valley of Morávka stream, 2.8 NW of the edge of Morávka village, in a garden, 430 m a.s.1., bark of Tilia cordata, Malus sp. \& Fraxinus excelsior, leg. Nociarová 24.VII.2006, det. Plášek (OP).

$1.7 \mathrm{~km}$ SW of Morávka village, upper part of valley of Vlašský potok stream, edge of a forest, $610 \mathrm{~m}$ a.s.1., bark of Fraxinus excelsior \& Salix sp., leg. Nociarová 20.VII.2006, det. Plášek (OP).

$1.8 \mathrm{~km}$ WNW of Morávka village, middle part of valley of Vlašský potok stream, in a garden, $500 \mathrm{~m}$ a.s.l., bark of Malus sp., leg. Nociarová 20.VII.2006, det. Plášek (OP).

Mořkov

$2.8 \mathrm{~km}$ SE of Mořkov village, along red tourist path, 729 m a.s.l., bark of Fagus sylvatica, leg. Hradilová 6.X.2007, det. Plášek (OP).

1.3-2.5 km SE of Mořkov village, near a touristic path, $480 \mathrm{~m}$ a.s.1., bark of Sambucus nigra, Salix caprea \& Ulmus glabra, leg. Hradilová 12.VIII.2007, det. Plášek (OP).

2 km SE of Mořkov village, along yellow tourist path, 602 m a.s.l., bark of Sambucus racemosa, leg. Hradilová 6.X.2007, det. Plášek (OP)

$2.5 \mathrm{~km} \mathrm{~S}$ of Mořkov village, S slope of Huštýn hill, near a forest road, $580 \mathrm{~m}$ a.s.1., bark of Salix sp., leg. Hradilová 20.VIII.2007, det. Plášek (OP). 
1 km SE of Mořkov village, loc. "Pod Huštýnem", 480 m a.s.l., bark of Sorbus aucuparia \& Salix sp., leg. Hradilová 20.VIII.2007, det. Plášek (OP).

3.3 km ESE of Mořkov village, near a touristic path, 500 m a.s.l., bark of Fagus sylvatica \& Sambucus nigra, leg. Hradilová 12.VIII.2007, det. Plášek (OP).

\section{Nýdek}

Nýdek village, along public road, near the chapel, 405 m a.s.1., bark of Acer pseudoplatanus, leg. Plášek 18.X.1999 (OP).

\section{Ondřejník}

SW slope of Ondřejník hill, $600 \mathrm{~m}$ NW of Kunčice pod Ondřejníkem village, $2.9 \mathrm{~km} \mathrm{~S}$ of the summit of the hill, $580 \mathrm{~m}$ a.s.1., bark of Malus sp., leg. Brus 10.X.2007, det. Plášek (OP).

Stará Ves nad Ondřejnicí village, along a public road, 240 m a.s.l., bark of tree Malus sp., leg. Plášek 5.VIII.2005 (OP).

SE slope of Ondřejník hill, $650 \mathrm{~m}$ SSE of the summit of the hill, along a forest road, $711 \mathrm{~m}$ a.s.l., bark of Acer platanoides, leg. Brus 14.IX.2007, det. Plášek (OP).

W slope of Ondřejník hill, $400 \mathrm{~m}$ W of the summit of the hill, along a forest road, $690 \mathrm{~m}$ a.s.l., bark of Sambucus nigra, leg. Brus 10.X.2007, det. Plášek (OP).

NE slope of Ondřejník hill, $955 \mathrm{~m} \mathrm{NE}$ of the summit of the hill, along a forest road, $697 \mathrm{~m}$ a.s.l., bark of Acer pseudoplatanus, leg. Brus 14.IX.2007, det. Plášek (OP).

\section{Ostravice}

Masarykovo údolí valley, 573 m a.s.1., bark of Fraxinus excelsior, leg. Pasečná 18.VIII.2008, det. Plášek (OP).

Pustevny

$3.2 \mathrm{~km}$ SSE of Pustevny settlement, $2 \mathrm{~km}$ NE of Bácov village, along a public road, $594 \mathrm{~m}$ a.s.l., bark of Fraxinus excelsior, leg. Štefúnová 16.IX.2007, det. Plášek (OP).

1.5 km WNW of Pustevny Mt., under Velká sjezdovka ski slope, 850 m a.s.l., bark of tree Acer pseudoplatanus, leg. Plášek 10.II.2007 (OP).

Rožnov p. R.

Edge of Hutisko-Solanec village, 500 m a.s.l., bark of Malus sp., leg. Plášek 5.VII.2001 (OP).

Staré Hamry

$300 \mathrm{~m}$ NE of Staré Hamry settlement, $1 \mathrm{~km} \mathrm{~S}$ of Príslop hill, valley of Černá Ostravice stream, $517 \mathrm{~m}$ a.s.l., bark of Salix caprea, leg. Plášek 12.IX.2006 (OP).

Staré Hamry village, in a garden, 550 m a.s.l., bark of a deciduous tree, leg. Duda 25.IX.2005, det. Plášek (priv. coll. Duda).

Trojanovice

S edge of Trojanovice village, loc. "U Báčů", 431 m a.s.l., bark of Malus sp. \& Populus nigra, leg. Plášek 3.V.2007 (OP).

Edge of Trojanovice village, valley of Radhoštnice stream, near hotel "Gurmán", 560 m a.s.l., bark of Salix caprea, leg. Plášek 16.X.2008 (OP).

\section{O. Lyellii Hook. et Taylor}

\section{Horní Bečva}

1 km NNE of Horní Bečva village, $675 \mathrm{~m} \mathrm{~W}$ of Kobylská hill, 669 m a.s.l., bark of Fraxinus excelsior, leg. Štefúnová 14.IX.2007, det. Plášek (OP).

\section{Nýdek}

Nýdek village, near a chaple 480 m a.s.l., bark of Acer pseudoplatanus, leg. Plášek 1.X.1999 (OP).

Rožnov p. R.

Rožnov pod Radhoštěm town, Skanzen open-air museum, 390 m a.s.1., bark of Fraxinus excelsior, Plášek 11.II.2007 (OP).

Velké Karlovice

4 km E of Velké Karlovice village, Malá Hanzlůvka valley, 700 m a.s.l., leg. Kašpar 24.XI.2000, teste Plášek \& Duda (VM).

\section{O. moravicum Plášek \& Sawicki}

Bílá

$3 \mathrm{~km}$ NE of Bílá village, valley of Chladná voda stream, $645 \mathrm{~m}$ a.s.l., bark of Salix caprea, leg. Pasečná \& Plášek 31.VII.2006 (OP - TYPUS).

\section{O. pallens Bruch ex Brid.}

\section{Bílá}

1.3-1.5 km NE of Bílá village, valley of Černá Ostravice stream, 533-544 m a.s.1., bark of Salix caprea \& Tilia platyphyllos, leg. Pasečná 4.VII.2006, det. Plášek (OP).

1.6-2.4 km E of Bílá village, valley of left confluence of Chladná Voda stream, 581-704 m a.s.1., bark of Salix caprea, Sorbus aucuparia, Acer pseudoplatanus \& Malus sp., leg. Pasečná \& Plášek 31.VII.2006 \& 9.VII.2007 (OP).

$2.3 \mathrm{~km}$ NE of Bílá village \& $6.2 \mathrm{~km}$ SW of loc. Bílý Kř́žz, middle part of Černá Ostravice stream valley, $552 \mathrm{~m}$ a.s.l., bark of Alnus incana, leg. Pasečná 4.VII.2006, det. Plášek (OP).

W edgeof Bílá village, part Zámeček, $550 \mathrm{~m}$ a.s.l., bark of Sorbus aucuparia, Malus sp. \& Tilia cordata, leg. Plášek 9.XII.2006 (OP).

Bílý Kříž

Loc. "Bílý Kř́ž", ca. 150 m NW of Czech-Slovak border line \& 500 m SSW of Sulov hill, 849 m a.s.l., bark of Acer pseudoplatanus, leg. Plášek 12.IX.2006 (OP). 
2 km NNE of Sulov hill, Byčinec Reserve, 700 m a.s.1., bark of Sorbus aucuparia, leg. Plášek 9.VI.2009 (OP).

Čeladná

7.5 - $8.5 \mathrm{~km} \mathrm{~S}$ of Čeladná village, loc. "Pod kaštany", alley of old deciduous trees, $610 \mathrm{~m}$ a.s.1., bark of Aesculus hippocastanum, leg. Plášek 25.IX.2005 (OP).

Frenštát

2.8 km SW of Frenštát pod Radhoštěm town, E slope of Velký Javorník hill, 820 m a.s.l., bark of Acer campestre, leg. Hradilová 20.IX.2007, leg. Plášek (OP).

Horní Bečva

Opálený settlement, 537 m a.s.l., bark of Salix fragilis, leg. Štefúnová 20.IX.2007, det. Plášek (OP).

$500 \mathrm{~m}-1.1 \mathrm{~km}$ ENE of Opálený settlement, $1.8 \mathrm{~km}$ SW of Kudlačena reserve, 592-655 m a.s.1., bark of Salix caprea \& Malus $s p$. , leg. Štefúnová 20.IX.2007, det. Plášek (OP).

1.8 km NNE of Horní Bečva village, 800 m WSW of Bukoviny settlement, valley of Kobylská stream, 593 m a.s.1., bark of Fraxinus excelsior, leg. Štefúnová 14.IX.2007, det. Plášek (OP).

Horní Bečva village, $1.2 \mathrm{~km} \mathrm{~N}$ of Opálený settlement, valley of Mečůvka stream, $542 \mathrm{~m}$ a.s.1., bark of Malus sp., Acer pseudoplatanus \& Fraxinus excelsior, leg. Štefúnová 20.IX.2007, det. Plášek (OP).

$1.6 \mathrm{~km} \mathrm{~N}$ of Podlízaná settlement, $240 \mathrm{~m} \mathrm{SW}$ of Kladnatá hill, $813 \mathrm{~m}$ a.s.l., bark of Fraxinus excelsior, leg. Štefúnová 20.IX.2007, det. Plášek (OP).

\section{Horní Lomná}

Horní Lomná village, centre of the village, along public road, 600 m a.s.l., bark of Sorbus sp., leg. Plášek 24.VII.2000 (OP).

S edge of Horní Lomná village, 585 m a.s.l., bark of Fraxinus excelsior, leg. Plášek 5.XI.2005 (OP).

Lysá hora

$500 \mathrm{~m}$ ENE of Těšiňoky settlement, valley of Řečica stream, 4 km SSE of the top of Lysá hora Mt., $580 \mathrm{~m}$ a.s.l., bark of Acer pseudoplatanus, leg. Plášek 6.IX.2003 (OP).

ENE edge of Těšiňoky settlement, valley of Řečica stream, $4.5 \mathrm{~km} \mathrm{SSE}$ of the top of Lysá hora Mt., $585 \mathrm{~m}$ a.s.1., bark of Malus sp., leg. Plášek 6.IX.2003 (OP).

NW edge of Vyšní Mohelnice settlement, 3815 m SE of the top of Lysá hora Mt., 815 m a.s.l., bark of Malus sp., leg. Plášek 6.IX.2003 (OP)

Mionší

Top of Menší vrch hill, Mionší Reserve, loc. "Velká polana" meadow, 880 m a.s.l., bark of Fagus sylvatica, leg. Plášek 29.VII.2005 (OP).

\section{Morávka}

1 km NE of Morávka village, SE slope of Malý Lipový hill, 600 m a.s.1., bark of Pyrus sp., Juglans regia \& Malus sp., leg. Nociarová 29.VII.2006, det. Plášek (OP).

$1.5 \mathrm{~km}$ NE of Morávka village, valley of Malý Lipový potok stream, $450 \mathrm{~m}$ a.s.l., bark of Acer pseudoplatanus, leg. Nociarová 18.VII.2006, det. Plášek (OP).

$1.7 \mathrm{~km} \mathrm{SW}$ of Morávka village, upper part of valley of Vlašský potok stream, $610 \mathrm{~m}$ a.s.l., bark of Acer platanoides \& Fraxinus excelsior, leg. Nociarová 20.VII.2006, det. Plášek (OP).

$1.8 \mathrm{~km}$ WNW of Morávka village, middle part of valley of Vlašský potok stream, in a garden, $500 \mathrm{~m}$ a.s.l., bark of Malus $s p$., leg. Nociarová 20.VII.2006, det. Plášek (OP).

$2.1 \mathrm{~km}$ NE of Morávka village, SW edge of Velký Lipový settlement, right tributary of Velký Lipový stream, $550 \mathrm{~m}$ a.s.1., bark of Malus sp., Salix sp., Acer platanoides \& Fraxinus excelsior, leg. Nociarová 25.VII.2006, det. Plášek (OP).

$2.8 \mathrm{NW}$ of the edge of Morávka village, between Morávka and Pražmo villages, valley of Morávka stream, in a garden near a forest, 430 m a.s.l., bark of Fraxinus excelsior, leg. Nociarová 24.VII.2006, det. Plášek (OP).

\section{Mořkov}

$1.3 \mathrm{~km}$ SE of Mořkov village, near a touristic path, $480 \mathrm{~m}$ a.s.l., bark of Salix caprea, leg. Hradilová 12.VIII.2007, det. Plášek (OP)

\section{Nýdek}

Nýdek village, valley of Hluchová stream, 460 m a.s.l., leg. Plášek 1.X.1999 (OP).

Nýdek village, between loc. "Guty" and "Gora", valley of Horský potok stream, 480 m a.s.l., leg. Plášek 30.IX.1999 (OP).

Nýdek village, near a chaple, 480 m a.s.l., bark of Acer pseudoplatanus, leg. Kučera 1.10.1999, teste Plášek (priv. coll. Kučera).

\section{Ostravice}

Masarykovo údolí valley, 527-553 m a.s.l., bark of Salix caprea, Acer pseudoplatanus \& Fraxinus excelsior, leg. Pasečná 18.VIII.2008, det. Plášek (OP).

Ostrý

WSW slope of Ostrý Mt., $60 \mathrm{~m}$ WSW of the summit of the Mt, Čerňavina Reserve, $1020 \mathrm{~m}$ a.s.1., bark of Fagus sylvatica, leg. Plášek 15.IX.2007 (OP).

\section{Pustevny}

2 km SE of Pustevny settlement, along a public road, 636 m a.s.1., bark of Acer pseudoplatanus, leg. Štefúnová 16.IX.2007, det. Plášek (OP).

3.2-3.4 km SSE of Pustevny settlement, $2 \mathrm{~km}$ NE of Bácov village, along a public road, 567-594 m a.s.1., bark of Malus sp. \& Fraxinus excelsior, leg. Štefúnová 16.IX.2007, det. Plášek (OP).

\section{Staré Hamry}

300-350 m NE of Staré Hamry settlement, 1 km S of Príslop hill, valley of Černá Ostravice stream, 517 m a.s.1., bark of Tilia cordata, Salix caprea, Aesculus hippocastanum \& Malus sp., leg. Plášek 12.IX.2006 (OP). 
$500 \mathrm{~m} \mathrm{~W}$ of Staré Hamry settlement, $1.2 \mathrm{~km} \mathrm{SSW}$ of Príslop hill, valley of Černá Ostravice stream, $501 \mathrm{~m}$ a.s.1., bark of Alnus incana, leg. Plášek 12.IX.2006 (OP).

690 m NE of Staré Hamry settlement, valley of Černá Ostravice stream, 950 m SE of Príslop hill, 550 m a.s.1., bark of Acer pseudoplatanus, leg. Plášek 12.IX.2006 (OP).

Staré Hamry settlement, 505 m a.s.1., bark of Salix fragilis, leg. Plášek 12.IX.2006 (OP).

2.5 km NE od Staré Hamry village, Podgrúň Reserve, 800 m a.s.l., bark of Salix sp., leg. Plášek 9.VIII.2009 (OP).

Vigantice

2 km SW of Vigantice village, loc. "Na Vápenkách", valley of Měřistek stream, 460 m a.s.l., bark of Sambucus nigra, leg. Plášek 24.IX.2005 (OP).

\section{O. patens Bruch ex Brid.}

\section{Staré Hamry}

353-690 m NE of Staré Hamry settlement, valley of Černá Ostravice stream, $950 \mathrm{~m}$ - 1 km SE of Príslop hill, 533-550 m a.s.1., bark of Aesculus hippocastanum \& Acer pseudoplatanus, Plášek 12.IX.2006 (OP).

\section{O. pumilum Sw. ex anon}

\section{Bílá}

1.5 km NE of Bílá village, valley of Černá Ostravice stream, 533 m a.s.l., bark of Salix caprea, leg. Pasečná 4.VII.2006, det. Plášek (OP).

W edge of Bílá village, part Zámeček, 555 m a.s.l., bark of Acer pseudoplatanus \& Malus sp., leg. Plášek 9.XII.2006 (OP).

Bystřice n.O.

E edge of Bystřice nad Olší village, 450 m a.s.l., a bridge, leg. Plášek 29.V.2001 (OP).

Bukovec

$1 \mathrm{~km} \mathrm{NE}$ of Bukovec village, along a public road, apple orchard, $465 \mathrm{~m}$ a.s.l., bark of Pyrus sp. \& Malus sp., leg. Plášek 23.VII.2004 (OP).

\section{Čeladná}

3 km S of Čeladná village, loc. "Hamry", 489 m a.s.l., bark of Acer pseudoplatanus \& Malus sp., leg. Plášek \& Stebel 25.IX.2005 (OP, SOSN).

\section{Dobrá}

$3 \mathrm{~km}$ E of Dobrá town, $1.5 \mathrm{~km} \mathrm{SW}$ of Vojkovice village, along public road, $343 \mathrm{~m}$ a.s.l., bark of Malus sp., leg. Plášek 23.VII.2004 (OP)

\section{Dolní Lomná}

Dolní Lomná village, centre of the village near "Pod Akáty" pub, 466 m a.s.1., bark of Populus sp., leg. Plášek 28.VII.2005 (OP).

Frenštát p.R.

2.8 km SW of Frenštát pod Radhoštěm town, E slope of Velký Javorník hill, 820 m a.s.l., bark of Acer campestre, leg. Hradilová 20.IX.2007, det. Plášek (OP).

\section{Hodslavice}

$1 \mathrm{~km} \mathrm{SSW}$ of edge of Hoslavice village \& $600 \mathrm{~m}$ SE of edge of Hostašovice village, "Prameny Zrzávky I." Nature Monument, bark of Salix fragilis, leg. Plášek 30.VI.2004 (OP).

Horní Bečva

1 km NNE of Horní Bečva village, 675 m W of Kobylská hill, 669 m a.s.l., bark of Fraxinus excelsior, leg. Štefúnová 14.IX.2007, det. Plášek (OP).

Horní Bečva village, 360-415 m N of Opálený settlement, valley of Mečůvka stream, 524-542 m a.s.l., bark of Acer pseudoplatanus \& Fraxinus excelsior, leg. Štefúnová 20.IX.2007, det. Plášek (OP).

$230 \mathrm{~m} \mathrm{~N}$ of Horní Bečva village, valley of Kobylská stream, $505 \mathrm{~m}$ a.s.l., bark of Fraxinus excelsior \& Pyrus sp., leg. Štefúnová 14.IX.2007, det. Plášek (OP).

1.5 km NE of Horní Bečva village, between loc. "U Tomšů" \& "Kudlačena", old apple orchard, 663 m a.s.l., bark of Malus sp., leg. Plášek 4.V.2007 (OP).

2 km NNE of Horní Bečva village, valley of Kobylská stream, Bukoviny settlement, $607 \mathrm{~m}$ a.s.l., bark of Malus sp., leg. Štefúnová 14.IX.2007, det. Plášek (OP).

$1.6 \mathrm{~km}$ N of Podlízaná settlement, $240 \mathrm{~m} \mathrm{SW}$ of Kladnatá hill, $813 \mathrm{~m}$ a.s.1., bark of Salix caprea, leg. Štefúnová 20.IX.2007, det. Plášek (OP).

$560 \mathrm{~m}$ SE of the top of Kladnatá hill, valley of Radhošt'nice stream, along tourist path, near an old quarry, $660 \mathrm{~m}$ a.s.1., bark of Salix caprea, leg. Plášek 3.V.2007 (OP).

\section{Horní Lomná}

S edge of Horní Lomná village, along a tour. path (yellow sign), 531 m a.s.l., bark of Acer pseudoplatanus, Tilia cordata \& Salix fragilis, leg. Plášek 5.XI.2005 (OP).

\section{Hrádek}

Between Hrádek nad Olší village and "V Pasekách" settlement, 2 km NNW of the village, $405 \mathrm{~m}$ a.s.l., bark of Juglans regia \& Malus sp., and rarely on a concrete wall, leg. Plášek 12.X.2001 (OP).

Hutisko-Solanec

Hutisko-Solanec village, 500 m a.s.l., bark of Malus sp., leg. Plášek 5.VII.2001 (OP). 


\section{Jablunkov}

Jablunkov town, Radvanov settlement, valley of Radvanov stream, 430 m a.s.l., bark of tree, leg. Plášek 3.VIII.2000 (OP).

\section{Morávka}

1 km NE of Morávka village, SE slope of Malý Lipový hill, 600 m a.s.1., bark of Malus sp., leg. Nociarová 29.VII.2006, det. Plášek (OP).

$1.7 \mathrm{~km} \mathrm{SW}$ of Morávka village, upper part of valley of Vlašský potok stream, edge of a forest, $610 \mathrm{~m}$ a.s.l., bark of Acer pseudoplatanus, leg. Nociarová 20.VII.2006, det. Plášek (OP).

$1.8 \mathrm{~km}$ WNW of Morávka village, middle part of valley of Vlašský potok stream, in a garden, $500 \mathrm{~m}$ a.s.1., bark of Malus $s p$., leg. Nociarová 20.VII.2006, det. Plášek (OP).

$2.1 \mathrm{~km}$ NE of Morávka village, SW edge of Velký Lipový settlement, right tributary of Velký Lipový stream, $550 \mathrm{~m}$ a.s.1., bark of Malus sp. \& Fraxinus excelsior, leg. Nociarová 25.VII.2006, det. Plášek (OP).

2.8 NW of the edge of Morávka village, between Morávka and Pražmo villages, valley of Morávka stream, in a garden, 430 m a.s.1., bark of Malus sp. \& Fraxinus excelsior, leg. Nociarová 24.VII.2006, det. Plášek (OP).

\section{Mořkov}

1 km SE of Mořkov village, loc. "Pod Huštýnem", 480 m a.s.l., bark of Salix sp. \& Ulmus minor, leg. Hradilová 20.VIII.2007, det. Plášek (OP).

1.3-4.2 km SE of Mořkov village, near a touristic path, 480-843 m a.s.1., bark of Acer pseudoplatanus, Fagus sylvatica, Sambucus nigra, Salix caprea \& Fraxinus excelsior, leg. Hradilová 12.VIII.2007 \& 4.IX.2007, det. Plášek (OP).

$2.5 \mathrm{~km} \mathrm{~S}$ of Mořkov village, S slope of Huštýn hill, near a forest road, $580 \mathrm{~m}$ a.s.l., bark of Salix caprea \& Ulmus glabra, leg. Hradilová 12.VIII.2007 \& 20.VIII.2007, det. Plášek (OP).

$2.7 \mathrm{~km}$ SSE of Hodslavice village \& $2.3 \mathrm{~km}$ SW of Mořkov village, loc. "Mořkovský les" forest, $650 \mathrm{~m}$ a.s.l., bark of Ulmus glabra, leg. Hradilová 20.VIII.2007, det. Plášek (OP).

$3.3 \mathrm{~km}$ ESE of Mořkov village, near a touristic path, $500 \mathrm{~m}$ a.s.1., bark of leg. Hradilová 12.VIII.2007, det. Plášek (OP).

$5 \mathrm{~km}$ ESE of Mořkov village, along red tourist path, 775 m a.s.1., bark of Acer pseudoplatanus, leg. Hradilová 6.X.2007, det. Plášek (OP).

\section{Nýdek}

NE edge of Nýdek village, 400 m a.s.1., bark of tree, leg. Klvaňová 17.V.2003, det. Plášek (OP).

NE edge of Nýdek village, valley of Hluchová stream, 480 m a.s.l., bark of tree, leg. Plášek 17.V.2003 (OP).

Nýdek village, along public road, near the chapel, 405 m a.s.l., bark of Acer pseudoplatanus, leg. Kučera 1.X.1999 (priv. coll. Kučera) \& leg. Plášek 18.X.1999 (OP).

Nýdek village, near loc. Guty and Gora, valley of Horský potok stream, 510 m a.s.l., bark of Acer pseudoplatanus, Novotný 30.IX.1999 (BRNM).

\section{Ondřejník}

SE slope of Ondřejník hill, $2 \mathrm{~km} \mathrm{NW}$ of Čeladná village, $2 \mathrm{~km} \mathrm{SE}$ of the summit of the hill, $710 \mathrm{~m}$ a.s.l., bark of Acer platanoides, Quercus robur, Tilia cordata, Fraxinus excelsior \& Carpinus betulus, leg. Brus 1.XI.2007, det. Plášek (OP).

E slope of Ondřejník hill, $3.2 \mathrm{~km} \mathrm{NW}$ of Čeladná village, $1.1 \mathrm{~km}$ E of the summit of the hill, $750 \mathrm{~m}$ a.s.l., bark of Acer pseudoplatanus, leg. Brus 1.XI.2007, det. Plášek (OP).

NE slope of Ondřejník hill, $540 \mathrm{~m}-1.3 \mathrm{~km} \mathrm{NE}$ of the summit of the hill, along a forest road, $662 \mathrm{~m}$ a.s.l., bark of Acer pseudoplatanus, leg. Brus 14.IX.2007 \& 10.X.2007, det. Plášek (OP).

SE slope of Ondřejník hill, 620-650 m SE of the summit of the hill, along a forest road, $749 \mathrm{~m}$ a.s.1., bark of Fraxinus excelsior, leg. Brus 14.IX.2007 \& 27.IX.2007, det. Plášek (OP).

SE slope of Ondřejník hill, $800 \mathrm{~m} \mathrm{SW}$ of Frýdlant nad Ostravicí town, $800 \mathrm{~m}$ SE of the summit of the hill, $750 \mathrm{~m}$ a.s.l., bark of Fraxinus excelsior, leg. Brus 1.XI.2007, det. Plášek (OP).

Stará Ves nad Ondřejnicí village, along a public road, 240 m a.s.l., bark of Malus sp., leg. Plášek 5.VIII.2005 (OP).

SW slope of Ondřejník hill, $600 \mathrm{~m}$ NW of Kunčice pod Ondřejníkem village, $2.9 \mathrm{~km} \mathrm{~S}$ of the summit of the hill, $580 \mathrm{~m}$ a.s.1., bark of Malus sp., leg. Brus 10.X.2007, det. Plášek (OP)

\section{Ostravice}

$1.5 \mathrm{~km}$ NE of Bílá village, valley of Černá Ostravice stream, 533 m a.s.l., bark of Salix caprea, leg. Pasečná 4.VII.2006, det. Plášek (OP).

ESE of Ostravice village, Mazák valley, $400 \mathrm{~m}$ a.s.l., bark of Aesculus hippocastanum, Plášek 31.V.2002 (OP).

Frýdlant nad Ostravicí town, Nová Ves village, valley of Ostravice stream, $400 \mathrm{~m}$ a.s.l., bark of Carpinus betulus, leg. Plášek 1.III.1998 (OP).

Ostravice village, along a public road, 500 m a.s.l., bark of Salix sp., leg. Plášek 24.V.2000 (OP)

SW edge of Ostravice village, $460 \mathrm{~m}$ a.s.1., bark of Malus sp., leg. Sovík 3.VIII.2004, det. Plášek (OP).

SW of Ostravice village, bank of Bučací potok stream, 470 m a.s.l., bark of Salix caprea, leg. Sovík 20.IV.2004, det. Plášek (OP).

SW of Ostravice village, under "Smrková cesta" road, 580 m a.s.1., bark of Acer pseudoplatanus, leg. Sovík 3.VIII.2004, det. Plášek (OP).

\section{Pustevny}

250-490 m S of Pustevny settlement, along a public road, 996-1002 m a.s.1., bark of Salix caprea, leg. Štefúnová 16.IX.2007, det. Plášek (OP).

1.7 km SE of Pustevny settlement, 1.2 km N of loc. "V Huti", 656 m a.s.1., bark of Salix caprea, leg. Štefúnová 16.IX.2007, det. Plášek (OP).

$3.2 \mathrm{~km}$ SSE of Pustevny settlement, $2 \mathrm{~km} \mathrm{NE}$ of Bácov village, along a public road, $594 \mathrm{~m}$ a.s.1., bark of Fraxinus excelsior, leg. Štefúnová 16.IX.2007 (OP).

$3.4 \mathrm{~km}$ SE of Pustevny settlement, $1.5 \mathrm{~km} \mathrm{SW}$ of Magurka Mt., $1011 \mathrm{~m}$ a.s.1., bark of Salix caprea, leg. Štefúnová 16.IX.2007, det. Plášek (OP). 


\section{Řečica}

Valley of Řečica stream, 625 m a.s.1., bark of tree, leg. Máchová 21.IX.2001, det. Plášek (OP).

\section{Staré Hamry}

Masarykovo údolí valley, 570 m a.s.1., bark of Salix caprea, leg. Pasečná 18.VIII.2008, det. Plášek (OP).

$2.5 \mathrm{~km} \mathrm{~W}$ of Staré Hamry village, $500 \mathrm{~m}$ SSW of Hutě village, along yellow touristic path, $538 \mathrm{~m}$ a.s.1., bark of Salix purpurea, leg. Sovík 15.IV.2005, det. Plášek (OP).

\section{Trojanovice}

S edge of Trojanovice village, loc. "U Báčũ", 431 m a.s.l., bark of Populus nigra \& Malus sp., leg. Plášek 3.V.2007 (OP).

S edge of Trojanovice village, valley of Radhoštnice stream, near hotel "Gurmán", 560 m a.s.l., bark of Salix caprea, leg. Plášek 16.X.2008 (OP).

\section{Věřovice}

$650 \mathrm{~m} \mathrm{~S}$ of Veřovice village, valley of Jičínka stream, $500 \mathrm{~m}$ a.s.l., bark of Swida sanquinea \& Sambucus nigra, leg. Hradilová 30.VIII.2007, det. Plášek (OP).

2 km SSE of Veřovice village, spring area of Jičínka stream, 695 m a.s.l., bark of Fagus sylvatica, leg. Hradilová 4.XI.2007, det. Plášek (OP).

$2.4 \mathrm{~km}$ SSE of Veřovice village, $470 \mathrm{~m}$ SE of Padolí settlement, $550 \mathrm{~m}$ a.s.l., bark of Acer pseudoplatanus, leg. Hradilová 30.VIII.2007, det. Plášek (OP).

\section{O. speciosum Nees}

\section{Bílá}

1.2-1.5 km NE of Bílá village, valley of Černá Ostravice stream, 533-562 m a.s.1., bark of Tilia platyphyllos \& Salix caprea, leg. Pasečná 4.VII.2006, det. Plášek (OP).

1.6-1.8 km E of Bílá village, valley of left confluence of Chladná Voda stream, $630 \mathrm{~m}$ a.s.l., bark of Acer pseudoplatanus \& Salix caprea, leg. Pasečná 31.VII.2006, det. Plášek (OP).

2.2-2.4 km E of Bílá village, valley of Chladná Voda stream, $646 \mathrm{~m}$ a.s.l., bark of Salix caprea, Sorbus aucuparia, Populus tremula \& Salix cinerea, leg. Plášek \& Pasečná 31.VII.2006 \& 9.VII.2007 (OP).

W edge of Bílá village, part Zámeček, 530-550 m a.s.l., bark of Sorbus aucuparia, Salix caprea, Acer pseudoplatanus, Malus sp. \& Tilia cordata, leg. Plášek 9.XII.2006 (OP).

\section{Bílý Kř́íz}

loc. Bílý Kř́žz, ca. 150 m NW of Czech-Slovak border line \& 500 m SSW of Sulov hill, 849 m a.s.l., bark of Fraxinus excelsior \& Acer pseudoplatanus, leg. Plášek 12.IX.2006 (OP).

loc. Bílý Kř́žz, ca. $740 \mathrm{~m}$ NW of Czech-Slovak border line \& $400 \mathrm{~m}$ NW of Sulov hill, $849 \mathrm{~m}$ a.s.1., bark of Fraxinus excelsior, leg. Plášek 12.IX.2006 (OP).

2 km NNE of Sulov hill, Byčinec Reserve, 700 m a.s.l., bark of Sorbus aucuparia, leg. Plášek 9.VI.2009 (OP).

Bukovec

$1 \mathrm{~km} \mathrm{NE}$ of Bukovec village, along a public road, apple orchard, $465 \mathrm{~m}$ a.s.1., bark of Malus sp., leg. Plášek 23.VII.2004 (OP).

Čeladná

7.5-8.5 km S of Čeladná village, loc. "Pod kaštany", alley of deciduous trees, 596-600 m a.s.1., bark of Salix caprea, Aesculus hippocastanum, leg. Plášek 25.IX.2005 (OP).

\section{Dolní Lomná}

$3.5 \mathrm{~km}$ SW of Dolní Lomná village, $1.8 \mathrm{~km}$ NNE of the summit of Velký Polom Mt., loc. "Dolínky", bark of Acer platanoides, leg. Plášek 29.IX.2007 (OP).

Dolní Lomná village, centre of the village, near "Pod Akáty" pub, 466 m a.s.l., bark of Populus sp., leg. Plášek 28.VII.2005 (OP).

\section{Frenštát p. R.}

2.8 km SW of Frenštát pod Radhoštěm town, E slope of Velký Javorník hill, 820 m a.s.l., bark of Acer campestre, leg. Hradilová 20.IX.2007, det. Plášek (OP).

3.2 km SW of Frenštát pod Radhoštěm town, the summit of Velký Javorník hill, 904 m a.s.1., bark of Salix caprea, leg. Hradilová 20.IX.2007, det. Plášek (OP).

\section{Horní Bečva}

Horní Bečva village, 360-415 m N of Opálený settlement, valley of Mečůvka stream, 524-542 m a.s.1., bark of Acer pseudoplatanus, leg. Štefúnová 20.IX.2007, det. Plášek (OP).

$1.1 \mathrm{~km}$ ENE of Opálený settlement (Horní Bečva village), $1 \mathrm{~km} \mathrm{SW}$ of Kudlačena reserve, $655 \mathrm{~m}$ a.s.1., bark of Betula pendula, leg. Štefúnová 20.IX.2007, det. Plášek (OP).

2.3-3 km NE of Horní Bečva village, $480 \mathrm{~m}$ NW of Mečůvka settlement, $746 \mathrm{~m}$ a.s.1., bark of Fraxinus excelsior \& Pyrus sp., leg. Štefúnová 14.IX.2007, det. Plášek (OP).

$1.6 \mathrm{~km}$ N of Podlízaná settlement, $240 \mathrm{~m} \mathrm{SW}$ of Kladnatá hill, $813 \mathrm{~m}$ a.s.l., bark of Fraxinus excelsior \& Salix caprea, leg. Štefúnová 20.IX.2007, det. Plášek (OP).

$560 \mathrm{~m} \mathrm{SE}$ of the top of Kladnatá hill, valley of Radhoštnice stream, along tourist path, near an old quarry, $660 \mathrm{~m}$ a.s.l., bark of Salix caprea, leg. Plášek 3.V.2007 (OP).

\section{Horní Lomná}

Horní Lomná village, centre of the village, along public road, $600 \mathrm{~m}$ a.s.l., bark of Fraxinus excelsior, leg. Plášek 24.VII.2000 (OP).

Horní Lomná village, near a touristic path towards Mionší reserve, 493 m a.s.l., bark of Fagus sylvatica, leg. Plášek 28.VII.2005 (OP). 
S edge of Horní Lomná village, 531-585 m a.s.1., bark of Fraxinus excelsior, Tilia cordata \& Salix fragilis, leg. Plášek 5.XI.2005 (OP).

Kněhyně

400 m NNE of the top of Čertův Mlýn Mt \& 800 m SW of the top of Kněhyně Mt, 1152 m a.s.l., bark of Sorbus sp., Plášek 6.IX.2005 (OP).

Lysá hora

ENE edge of Těšiňoky settlement, valley of Řečica stream, 4587 m SSE of the summit of Lysá hora Mt., 585 m a.s.1., bark of Acer pseudoplatanus, leg. Plášek 6.IX.2003 (OP).

\section{Masarykovo údolí}

Masarykovo údolí valley, 532 m a.s.l., bark of Fraxinus excelsior \& Acer pseudoplatanus, leg. Pasečná 18.VIII.2008, det. Plášek (OP).

\section{Mionší}

Top of Menší vrch hill, Mionší Reserve, loc. "Velká polana" meadow, 880 m a.s.l., bark of Fagus sylvatica, leg. Plášek 29.VII.2005 (OP).

\section{Morávka}

1.7 km SW of Morávka village, upper part of valley of Vlašský potok stream, edge of a forest, $610 \mathrm{~m}$ a.s.1., bark of Fraxinus excelsior \& Salix sp., leg. Nociarová20.VII.2006, det. Plášek (OP).

$2.1 \mathrm{~km}$ NE of Morávka village, SW edge of Velký Lipový settlement, right tributary of Velký Lipový stream, $550 \mathrm{~m}$ a.s.1., bark of Fraxinus excelsior, Salix sp. \& Malus sp., leg. Nociarová 25.VII.2006, det. Plášek (OP).

$2.7 \mathrm{~km}$ SE of Morávka village, upper part valley of Vlašský potok stream, edge of a forest, $785 \mathrm{~m}$ a.s.1., bark of Fraxinus excelsior, leg. Nociarová 24.VII.2006, det. Plášek (OP).

\section{Mořkov}

1 km SE of Mořkov village, loc. "Pod Huštýnem", 480 m a.s.l., bark of Salix sp., leg. Hradilová, 20.VIII.2007, det. Plášek (OP)

1.3-2.5 km SE of Mořkov village, near a touristic path, 480-500 m a.s.1., bark of Ulmus glabra \& Salix caprea, leg. Hradilová 12.VIII.2007, det. Plášek (OP).

$1.6 \mathrm{~km} \mathrm{~S}$ of Hodslavice village, along red tourist path, $400 \mathrm{~m}$ a.s.1., bark of Quercus sp., leg. Hradilová 6.IX.2007, det. Plášek (OP).

$2.7 \mathrm{~km}$ SSE of Hodslavice village \& $2.3 \mathrm{~km} \mathrm{SW}$ of Mořkov village, loc. Mořkovský les forest, $650 \mathrm{~m}$ a.s.l., bark of Ulmus glabra, leg. Hradilová 20.VIII.2007, det. Plášek (OP).

$3.3 \mathrm{~km}$ SE of Mořkov village, along red touristic path, $742 \mathrm{~m}$ a.s.1., bark of Acer pseudoplatanus, leg. Hradilová 6.X.2007, det. Plášek (OP).

Nýdek

Nýdek village, near a chaple, 480 m a.s.1., bark of Acer pseudoplatanus, leg. Kučera 1.X.1999, teste Plášek (priv. coll. Kučera).

Pustevny

1.7 km SE of Pustevny settlement, 1.2 km N of loc. "V Huti", 656 m a.s.1., bark of Salix caprea, leg. Štefúnová 16.IX.2007, det. Plášek (OP).

2 km ESE of Pustevny settlement, 880 m SW of Čertův Mlýn Mt, 935 m a.s.l., bark of Salix caprea, leg. Štefúnová 16.IX.2007, det. Plášek (OP).

$2.9 \mathrm{~km}$ SSE of Pustevny settlement, $2 \mathrm{~km}$ NE of Bácov village, along a public road, $573 \mathrm{~m}$ a.s.1., bark of Fraxinus excelsior, leg. Štefúnová 16.IX.2007, det. Plášek (OP).

$3.4 \mathrm{~km}$ SE of Pustevny settlement, $1.5 \mathrm{~km} \mathrm{SW}$ of Magurka Mt., $1011 \mathrm{~m}$ a.s.l., bark of Salix caprea, leg. Štefúnová 16.IX.2007, det. Plášek (OP).

490 m S of Pustevny settlement, along a public road, 996 m a.s.l., bark of Salix caprea, leg. Štefúnová 16.IX.2007, det. Plášek (OP).

Pustevny settlement, 1050 m a.s.l., bark of Salix caprea, leg. Plášek 10.V.2007 (OP).

Salajka

290 m NE of Bumbálka border settlement, edge of Salajka reserve, 862 m a.s.1., bark of Malus sp., leg. Plášek 9.XII.2006 (OP).

\section{Staré Hamry}

300-350 m NE of Staré Hamry settlement, 1 km S of Príslop hill, valley of Černá Ostravice stream, 517-530 m a.s.1., bark of Tilia cordata \& Aesculus hippocastanum, leg. Plášek 12.IX.2006 (OP).

$500 \mathrm{~m} \mathrm{~W}$ of Staré Hamry settlement, $1.2 \mathrm{~km}$ SSW of Príslop hill, valley of Černá Ostravice stream, $501 \mathrm{~m}$ a.s.1., bark of Alnus incana \& Fraxinus excelsior, leg. Plášek 12.IX.2006 (OP).

690 m NE of Staré Hamry settlement, valley of Černá Ostravice stream, 950 m SE of Príslop hill, 550 m a.s.1., bark of Acer pseudoplatanus, leg. Plášek 12.IX.2006 (OP).

2.5 km NE od Staré Hamry village, Podgrúň Reserve, 800 m a.s.1., bark of Salix sp., leg. Plášek 9.VIII.2009 (OP).

Věřovice

$650 \mathrm{~m} \mathrm{~S}$ of Veřovice village, valley of Jičínka stream, 500 m a.s.l., bark of Salix caprea, leg. Hradilová 30.VIII.2007, det. Plášek (OP).

2 km SE of Veřovice village, W slope of Velký Javorník hill, 799 m a.s.l., bark of Salix caprea \& Fagus sylvatica, leg. Hradilová 20.IX.2007 \& 4.XI.2007, det. Plášek (OP).

$2.4 \mathrm{~km}$ SSE of Veřovice village, $470 \mathrm{~m}$ SE of Padolí settlement, $550 \mathrm{~m}$ a.s.l., bark of Acer pseudoplatanus \& Salix sp., leg. Hradilová 30.VIII.2007, det. Plášek (OP). 


\section{O. stramineum Hornsch. ex Brid.}

\section{Bílá}

1.2-1.4 km NE of Bílá village, valley of Černá Ostravice stream, 524-544 m a.s.1., bark of Aesculus hippocastanum, Salix caprea, Fraxinus excelsior \& Tilia platyphyllos, leg. Pasečná 4.VII.2006, det. Plášek (OP).

$1.8 \mathrm{~km}$ ENE of Bílá village, valley of Chladná Voda stream, $620 \mathrm{~m}$ a.s.l., bark of Acer pseudoplatanus, leg. Pasečná 31.VII.2006, det. Plášek (OP).

$2.2 \mathrm{~km}$ E of Bílá village, valley of Chladná Voda stream, $646 \mathrm{~m}$ a.s.1., bark of Salix caprea, leg. Plášek 9.VII.2007 (OP).

$2.4 \mathrm{~km}$ E of Bílá village, middle part of Chladná voda stream valley, $660 \mathrm{~m}$ a.s.l., bark of Fagus sylvatica, leg. Pasečná 14.X.2006, det. Plášek (OP).

Bílý Kříž

loc. Bílý Kříž, ca. 150-450 m NW of Czech-Slovak border line \& 500 m SSW of Sulov hill, 849-875 m a.s.1., bark of Fraxinus excelsior \& Acer pseudoplatanus, leg. Plášek 12.IX.2006 (OP).

2 km NNE of Sulov hill, Byčinec Reserve, 700 m a.s.1., bark of Sorbus aucuparia, leg. Plášek 9.VI.2009 (OP).

Frenštát p.R.

2.8-3.2 km SW of Frenštát pod Radhoštěm town, E slope of Velký Javorník hill, 820-904 m a.s.1., bark of Acer campestre \& Salix caprea, leg. Hradilová 20.IX.2007, det. Plášek (OP).

Hodslavice

$1 \mathrm{~km}$ SSW of edge od Hodslavice village \& $600 \mathrm{~m}$ SE of edge of Hostašovice village, Prameny Zrzávky reserve, $392 \mathrm{~m}$ a.s.l., bark of Salix fragilis, leg. Plášek 30.VI.2004 (OP).

\section{Horní Bečva}

$510 \mathrm{~m}-1.7$ km NE of Horní Bečva village, 218-911 m N of Kobylská hill, 536-699 m a.s.1., bark of Fraxinus excelsior, Pyrus sp. \& Malus sp., leg. Štefúnová 14.IX.2007, det. Plášek (OP).

2 km NNE of Horní Bečva village, valley of Kobylská stream, Bukoviny settlement, 607 m a.s.l., bark of Fraxinus excelsior \& Salix caprea, leg. Štefúnová 14.IX.2007, det. Plášek (OP).

$3 \mathrm{~km} \mathrm{NE}$ of horní Bečva village, $720 \mathrm{~m} \mathrm{~N}$ of Mečůvka settlement, $782 \mathrm{~m}$ a.s.l., bark of Fraxinus excelsior, leg. Štefúnová 14.IX.2007, det. Plášek, (OP).

Horní Bečva village, 360 m N of Opálený settlement, valley of Mečůvka stream, 542 m a.s.l., bark of Fraxinus excelsior, leg. Štefúnová 20.IX.2007, det. Plášek (OP).

Opálený settlement (Horní Bečva village), 537 m a.s.1., bark of Salix fragilis, Leg. Štefúnová 20.IX.2007, det. Plášek (OP).

Horní Lomná

S edge of Horní Lomná village, along a tour. path (yellow sign), 533-585 m a.s.1., bark of Salix fragilis \& Fraxinus excelsior, leg. Plášek 5.XI.2005 (OP).

\section{Kněhyně}

Between Čertův Mlýn Mt and Kněhyně Mt, valley of Kněhyňský potok stream, 1030 m a.s.1., bark of Fagus sylvatica \& Acer pseudoplatanus, leg. Plášek 6.IX.2005 (OP).

Lysá hora

$400 \mathrm{~m} \mathrm{SW}$ of the summit of Lysá hora Mt., a beech forest, $1050 \mathrm{~m}$ a.s.1., bark of Ulmus glabra, leg. Plášek 22.VII.2003 (OP).

Mionší

Mionší reserve, NE slope of Menší vrch hill, 850 m a.s.l., bark of Acer pseudoplatanus, leg. Sovík 16.VI.2004, det. Plášek (OP).

\section{Morávka}

$1 \mathrm{~km}$ NE of Morávka village, SE slope of Malý Lipový hill, 600 m a.s.1., bark of Sambucus nigra \& Malus sp., leg. Nociarová 29.VII.2006, det. Plášek (OP).

$1.7 \mathrm{~km}$ SW of Morávka village, upper part of valley of Vlašský potok stream, edge of a forest, $610 \mathrm{~m}$ a.s.l., bark of Salix sp. \& Acer pseudoplatanus, leg. Nociarová 20.VII.2006, det. Plášek (OP).

$2.7 \mathrm{~km}$ SE of Morávka village, upper part valley of Vlašský potok stream, edge of a forest, $785 \mathrm{~m}$ a.s.1., bark of Acer pseudoplatanus, leg. Nociarová 24.VII.2006, det. Plášek (OP).

2.8 NW of the edge of Morávka village, between Morávka and Pražmo villages, valley of Morávka stream, in a garden, 430 m a.s.1., bark of Malus sp., leg. Nociarová 24.VII.2006, det. Plášek (OP).

\section{Mořkov}

2.3-2.5 km S of Mořkov village, S slope of Huštýn hill, near a forest road, 580-600 m a.s.1., bark of Acer pseudoplatanus \& Salix sp., leg. Hradilová 20.VIII.2007, det. Plášek (OP).

\section{Nýdek}

3 km NE of Nýdek village, S slope of Velká Čantoryje Mt, 828 m a.s.l., bark of Fraxinus excelsior, leg. Plášek 2.IX.2004 (OP).

4 km NNE of Nýdek village, middle part of the Velká Čantoryje reserve, S slope of Velká Čantoryje Mt, $900 \mathrm{~m}$ a.s.l., bark of Fagus sylvatica, leg. Plášek 21.IX.2000 (OP).

Nýdek village, between the village and Velká Čantoryje Mt., 900 m a.s.l., bark of tree, leg. Plášek 2.X.1999 (OP).

Nýdek village, loc. "Guty", valley of Horský potok stream, 490 m a.s.l., bark of tree, leg. Plášek 30.IX.1999 (OP).

Nýdek village, loc. "Pod chatou na Velké Čantoryji", 865 m a.s.l., bark of Fagus sylvatica, leg. Plášek 27.VIII.1997 (OP).

Nýdek village, near loc. "Guty" and "Gora", valley of Horský potok stream, 480 m a.s.l., bark of tree, leg. Plášek 30.IX.1999 (OP).

Velká Čantoryje Mt., between loc. "Za kámen" and top of the Velká Čantoryja Mt, along blue tourist path, $900 \mathrm{~m}$ a.s.l., bark of tree, leg. Plášek 2.X.1999 (OP).

Ondřejník 
SE slope of Ondřejník hill, $500 \mathrm{~m}$ SE of the summit of the hill, along a forest road, $743 \mathrm{~m}$ a.s.1., bark of Fraxinus excelsior, leg. Brus, 14.IX.2007, det. Plášek (OP).

NE slope of Ondřejník hill, 955m-1.2 km NE of the summit of the hill, along a forest road, 662-697 m a.s.1., bark of Acer pseudoplatanus \& Malus sp., leg. Brus 14.IX.2007, det. Plášek (OP).

SE of Kunčice pod Ondřejníkem village, NE slope of Stolová Mt., 1000 m a.s.l., bark of tree, leg. Duda 29.V.2004, det. Plášek (OP).

Ostravice

1.2-1.4 km NE of Bílá village, valley of Černá Ostravice stream, 524-544 m a.s.1., bark of Aesculus hippocastanum, Salix caprea, Tilia platyphyllos \& Fraxinus excelsior, leg. Pasečná 4.VII.2006, det. Plášek (OP).

$2 \mathrm{~km}$ SSE of Ostravice village, valley of Mazák, 450 m a.s.l., bark of Sambucus nigra, leg. Plášek 12.V.2005 (OP).

$3.5 \mathrm{~km}$ NE of Staré Hamry settlement, valley of Černá Ostravice stream, $1.2 \mathrm{~km}$ SE of Velký Lučný hill, 598 m a.s.1., bark of Salix caprea, leg. Plášek 12.IX.2006 (OP).

4 km SW of Ostravice village, SE slope of Smrk Mt., 1100 m a.s.l., bark of Acer pseudoplatanus, leg. Plášek 29.IX.2003 (OP).

$5.5 \mathrm{~km} \mathrm{SW}$ of Ostravice village, S slope of Smrk Mt., loc. Studenčany, upper part of Břestový potok stream, $850 \mathrm{~m}$ a.s.l., bark of Fagus sylvatica \& Acer pseudoplatanus, leg. Plášek 23.IX.2005 (OP).

SW of Ostravice village, under "Smrková cesta" road, 580 m a.s.l., bark of Acer pseudoplatanus, leg. Sovík 3.VIII.2004, det. Plášek (OP).

Ostrý

2.2-2.4 km SSE of Tyra village, NE slope of Ostrý Mt, 800-900 m a.s.1., bark of Fagus sylvatica, leg. Plášek 15.IX.2007 (OP).

ENE slope of Ostrý Mt., $30 \mathrm{~m} \mathrm{SSW}$ of the summit of the Mt, Čerňavina Reserve, 1040 m a.s.l., bark of Fagus sylvatica, leg. Plášek 15.IX.2007 (OP).

WSW slope of Ostrý Mt., 60 m WSW of the summit of the Mt, 1020 m a.s.1., bark of Fagus sylvatica, leg. Plášek 15.IX.2007 (OP).

Pustevny

485 m SE of Pustevny settlement, along a public road, 936 m a.s.1., bark of Salix caprea, leg. Štefúnová 16.IX.2007, det. Plášek (OP).

1.5 km WNW of Pustevny Mt., under Velká sjezdovka ski slope, $850 \mathrm{~m}$ a.s.l., bark of Acer pseudoplatanus, leg. Plášek 10.II.2007 (OP).

$3.2 \mathrm{~km}$ SSE of Pustevny settlement, $2 \mathrm{~km}$ NE of Bácov village, along a public road, $594 \mathrm{~m}$ a.s.1., bark of Fraxinus excelsior, leg. Štefúnová 16.IX.2007, det. Plášek (OP).

$3.4 \mathrm{~km}$ SE of Pustevny settlement, $1.5 \mathrm{~km}$ SW of Magurka Mt., $1011 \mathrm{~m}$ a.s.l., bark of Salix caprea, leg. Štefúnová 16.IX.2007, det. Plášek (OP).

Rožnov p. R.

Rožnov pod Radhoštěm town, Skanzen open-air museum, 390 m a.s.l., bark of Fraxinus excelsior, leg. Plášek 11.II.2007 (OP).

Salajka

290 m NE of Bumbálka border settlement, edge of Salajka reserve, 862 m a.s.1., bark of Malus sp., Plášek 9.XII.2006 (OP)

380 m ENE of Bumbálka border settlement, Salajka reserve, 800 m a.s.1., bark of Fagus sylvatica, leg. Plášek 9.XII.2006 (OP).

\section{Staré Hamry}

$3.5 \mathrm{~km}$ NE of Staré Hamry settlement, valley of Černá Ostravice stream, $1.2 \mathrm{~km}$ SE of Velký Lučný hill, 598 m a.s.l., bark of Salix caprea, leg. Plášek 12.IX.2006 (OP).

$2.5 \mathrm{~km}$ W of Staré Hamry village, $500 \mathrm{~m}$ SSW of Hutě village, along yellow touristic path, $538 \mathrm{~m}$ a.s.1., bark of Salix purpurea, leg. Sovík 15.IV.2005, det. Plášek (OP).

2.5 km NE od Staré Hamry village, Podgrún̆ Reserve, 800 m a.s.1., bark of Salix sp., leg. Plášek 9.VIII.2009 (OP).

\section{O. striatum Hedw.}

\section{Horní Lomná}

S edge of Horní Lomná village, 585 m a.s.l., bark of Fraxinus excelsior, leg. Plášek 5.XI.2005 (OP).

Mionší

Top of Menší vrch hill, Mionší Reserve, loc. "Velká Polana" meadow, 880 m a.s.l., bark of Fagus sylvatica, Plášek 29.VII.2005 (OP).

\section{Morávka}

$1.7 \mathrm{~km} \mathrm{SW}$ of Morávka village, upper part of valley of Vlašský potok stream, edge of a forest, $610 \mathrm{~m}$ a.s.l., bark of Fraxinus excelsior, leg. Nociarová 20.VII.2006, det. Plášek (OP).

Pustevny

$3.2 \mathrm{~km}$ SSE of Pustevny settlement, $2 \mathrm{~km}$ NE of Bácov village, along a public road, $594 \mathrm{~m}$ a.s.1., bark of Fraxinus excelsior, leg. Štefúnová 16.IX.2007, det. Plášek (OP). 
Ulota bruchii Hornsch. ex Brid.

Bílá

2-2.4 km ENE of Bílá village, middle part of Chladná voda stream valley, 643-660 m a.s.l., bark of Populus tremula \& Salix caprea, leg. Pasečná 31.VII.2006, det. Plášek (OP).

$1.5 \mathrm{~km}$ NE of Bílá village, valley of Černá Ostravice stream, 533-552 m a.s.1., bark of Salix caprea, leg. Pasečná 4.VII.2006, det. Plášek (OP).

2.1-5.4 km NE of Bílá village towards loc. "Bílý Kř́ž", middle part of Černá Ostravice stream valley, 554 m a.s.l., bark of Alnus incana, Picea abies \& Alnus glutinosa, leg. Pasečná 4.7.2006 \& 11.7.2006, det. Plášek (OP).

Bílý Kř́íž

Loc. "Bílý Kříž", 150 m NW of Czech-Slovak border line \& 500 m SSW of Sulov hill, 849 m a.s.l., bark of Salix caprea, leg. Plášek 12.IX.2006 (OP).

Dolní Lomná

$3.5 \mathrm{~km} \mathrm{SW}$ of Dolní Lomná village, $1.8 \mathrm{~km}$ NNE of the summit of Velký Polom Mt, loc. "Dolínky", bark of Acer platanoides, leg. Plášek 29.IX.2007 (OP).

Frenštát p. R.

2.8-3.2 km SW of Frenštát pod Radhoštěm town, the summit of Velký Javorník hill, 820-904 m a.s.1., bark of Salix caprea \& Acer campestre, leg. Hradilová 20.IX.2007, det. Plášek (OP).

Horní Bečva

Horní Bečva village, 50-360 m N of Opálený settlement, valley of Mečůvka stream, 531-542 m a.s.l., bark of Fraxinus excelsior, leg. Štefúnová 20.IX.2007, det. Plášek (OP).

$1.6 \mathrm{~km}$ N of Podlízaná settlement, 240 m SW of Kladnatá hill, 813 m a.s.1., bark of Salix caprea, leg. Štefúnová 20.IX.2007, det. Plášek (OP).

Horní Lomná

S edge of Horní Lomná village, along a touristic path (yellow sign), 533 m a.s.1., bark of Salix fragilis, leg. Plášek 5.XI.2005 (OP).

Kněhyně

Between Čertův Mlýn Mt. and Kněhyně Mt, valley of Kněhyňský potok stream, 1030 m a.s.l., bark of Fagus sylvatica, leg. Plášek 6.IX.2005 (OP).

Lysá hora

ENE edge of Těšiňoky settlement, valley of Řečica stream, $4587 \mathrm{~m} \mathrm{SSE}$ of the summit of Lysá hora Mt, $585 \mathrm{~m}$ a.s.1., bark of Acer pseudoplatanus, leg. Plášek 6.IX.2003 (OP).

Masarykovo údolí

Masarykovo údolí valley, loc. "Poledňana", 527 m a.s.l., bark of Acer pseudoplatanus, leg. Pasečná 18.VIII.2008. det. Plášek (OP).

Mionší

E slope of Menší vrch hill, Mionší reserve, 700 m a.s.1., bark of Acer pseudoplatanus, leg. Plášek 28.VII.2005 (OP)

Mionší reserve, $400 \mathrm{~m}$ under spring area of Menší potok stream, $550 \mathrm{~m}$ a.s.l., bark of Acer pseudoplatanus, leg. Plášek 28.VII.2005 (OP)

Morávka

$1.7 \mathrm{~km} \mathrm{SW}$ of Morávka village, upper part of valley of Vlašský potok stream, edge of a forest $610 \mathrm{~m}$ a.s.l., bark of Acer pseudoplatanus \& Fraxinus excelsior, leg. Nociarová 20.VII.2006, det. Plášek (OP).

Mořkov

1 km SE of Mořkov village, loc. Pod Huštýnem, 480 m a.s.l., bark of Ulmus minor, leg. Hradilová 20.VIII.2007, det. Plášek (OP).

$1.3 \mathrm{~km}$ SE of Mořkov village, near a touristic path, $480 \mathrm{~m}$ a.s.1., bark of Salix caprea, leg. Hradilová 12.VIII.2007, det. Plášek (OP).

$2 \mathrm{~km}$ SE of Mořkov village, along yellow tourist path, 602 m a.s.1., bark of Sambucus racemosa, leg. Hradilová 6.X.2007, det. Plášek (OP).

$2.5 \mathrm{~km} \mathrm{~S}$ of Mořkov village, S slope of Huštýn hill, near a forest road, $580 \mathrm{~m}$ a.s.l., bark of Salix sp., leg. Hradilová 20.VIII.2007, det. Plášek (OP).

2.6 km SE of Mořkov village, along red tourist path, 745 m a.s.l., bark of Fraxinus excelsior, leg. Hradilová 6.X.2007, det. Plášek (OP)

$2.7 \mathrm{~km}$ SSE of Hodslavice village \& $2.3 \mathrm{~km} \mathrm{SW}$ of Mořkov village, loc. Mořkovský les forest, $650 \mathrm{~m}$ a.s.1., bark of Ulmus glabra, leg. Hradilová 20.VIII.2007, det. Plášek (OP).

$3.3 \mathrm{~km}$ ESE of Mořkov village, near a touristic path, $500 \mathrm{~m}$ a.s.l., bark of Fagus sylvatica, leg. Hradilová 12.VIII.2007, det. Plášek (OP).

Nýdek

3 km ENE of Nýdek village, valley of Střelma river, 520 m a.s.l., bark of tree, leg. Plášek 3.IX.1999 (OP).

Ondřejník

NE slope of Ondřejník hill, 1.2-1.3 km NE of the summit of the hill, along a forest road 640-662 m a.s.1., bark of Juglans regia \& Acer pseudoplatanus, leg. Brus 14.IX.2007 \& 10.10.2007, det. Plášek (OP).

$\mathrm{S}$ slope of Ondřejník hill, $795 \mathrm{~m}$ SE of the summit of the hill, along a forest road, $820 \mathrm{~m}$ a.s.1., bark of Acer pseudoplatanus, leg. Brus 27.IX.2007, det. Plášek (OP).

Ostravice

3.5-5 km NE of Staré Hamry settlement, valley of Černá Ostravice stream, 1.2 km SE of Velký Lučný hill, 598-708 m a.s.1., bark of Salix caprea, Fagus sylvatica \& Fraxinus excelsior, leg. Plášek 12.IX.2006 (OP). 
$300 \mathrm{~m} \mathrm{NE}$ of Staré Hamry settlement, $1 \mathrm{~km} \mathrm{~S}$ of Príslop hill, valley of Černá Ostravice stream, 517 m a.s.l., bark of Salix caprea, leg. Plášek 12.IX.2006 (OP).

$4 \mathrm{~km}$ SW of Ostravice village, SE slope of Smrk Mt., 1100 m a.s.l., bark of Acer pseudoplatanus, leg. Plášek 29.IX.2003 (OP).

5.4 km NE of Bílá village \& 3.8 km SW of loc. "Bílý Křǐž", middle part of Černá Ostravice stream valley, $660 \mathrm{~m}$ a.s.l., bark of Alnus glutinosa, leg. Pasečná 11.VII.2006, det. Plášek (OP).

690 m NE of Staré Hamry settlement, valley of Černá Ostravice stream, 950 m SE of Príslop hill, 550 m a.s.1., bark of Acer pseudoplatanus, leg. Plášek 12.IX.2006 (OP).

Ostravice village, loc. Butořanka, 750 m a.s.l., bark of Acer pseudoplatanus, leg. Plášek 24.V.2000 (OP).

Pustevny

Pustevny settlement, 1050 m a.s.1., bark of Salix caprea, leg. Plášek 10.V.2007 (OP)

865 m-1.6 km SE of Pustevny settlement, along a public road, 800-864 m a.s.l., bark of Salix caprea, leg. Štefúnová 16.IX.2007, det. Plášek (OP).

$3.4 \mathrm{~km}$ SE of Pustevny settlement, $1.5 \mathrm{~km} \mathrm{SW}$ of Magurka Mt., $1011 \mathrm{~m}$ a.s.1., bark of Salix caprea, leg. Štefúnová 16.IX.2007, det. Plášek (OP).

Salajka

290 m NE of Bumbálka border settlement, edge of Salajka reserve, 862 m a.s.1., bark of Salix caprea, leg. Plášek 9.XII.2006 (OP).

Staré Hamry

$300 \mathrm{~m}$ NE of Staré Hamry settlement, $1 \mathrm{~km} \mathrm{~S}$ of Príslop hill, valley of Černá Ostravice stream, 517 m a.s.l., bark of Salix caprea, leg. Plášek 12.IX.2006 (OP).

$690 \mathrm{~m}$ NE of Staré Hamry settlement, valley of Černá Ostravice stream, 950 m SE of Príslop hill, $550 \mathrm{~m}$ a.s.l., bark of Acer pseudoplatanus, leg. Plášek 12.IX.2006 (OP).

3.5-5 km NE of Staré Hamry settlement, valley of Černá Ostravice stream, 1.2 km SE of Velký Lučný hill, 598-708 m a.s.1., bark of Salix caprea, Fagus sylvatica \& Fraxinus excelsior, leg. Plášek 12.IX.2006 (OP).

Trojanovice

S edge of Trojanovice village, valley of Radhoštnice stream, near hotel "Gurmán", 560 m a.s.1., bark of Salix caprea, leg. Plášek 16.X.2008 (OP).

Veřovice

$650 \mathrm{~m} \mathrm{~S}$ of Veřovice village, valley of Jičínka stream, $500 \mathrm{~m}$ a.s.l., bark of Salix caprea, leg. Hradilová 30.VIII.2007, det. Plášek (OP).

Ulota crispa (Hedw.) Brid.

\section{Bílá}

2.2-2.4 km E of Bílá village, valley of Chladná Voda stream, $646 \mathrm{~m}$ a.s.l., bark of Salix caprea, Sorbus aucuparia \& Populus tremula, leg. Plášek \& Pasečná 31.VII.2006 \& 9.VII.2007 (OP).

2.3-5.4 km NE of Bílá village towards loc. "Bílý Kříž", middle part of Černá Ostravice stream valley, 568-600 m a.s.l., bark of Alnus incana, Picea abies \& Alnus glutinosa, leg. Pasečná, det. Plášek 4.VII.2006 (OP).

Horní Bečva

1.1 km ENE of Opálený settlement, $1 \mathrm{~km} \mathrm{SW}$ of Kudlačena reserve, 655 m a.s.1., bark of Salix caprea, leg. Štefúnová 20.IX.2007, det. Plášek (OP).

$680 \mathrm{~m} \mathrm{~N}$ of Horní Bečva village, valley of Kobylská stream, 536 m a.s.l., bark of Fraxinus excelsior, leg. Štefúnová 14.IX.2007, det. Plášek (OP).

\section{Horní Lomná}

S edge of Horní Lomná village, 585 m a.s.1., bark of Fraxinus excelsior, leg. Plášek 5.XI.2005 (OP).

Lysá hora

500 m ENE of Těšiňoky settlement, valley of Řečica stream, 4300 m SSE of the summit of Lysá hora Mt, 580 m a.s.1., bark of Acer pseudoplatanus, leg. Plášek 6.X.2003 (OP).

Morávka

$1.7 \mathrm{~km}$ SW of Morávka village, upper part of valley of Vlašský potok stream, $610 \mathrm{~m}$ a.s.l., bark of Acer platanoides, leg. Nociarová 20.VII.2006, det. Plášek (OP).

$2.1 \mathrm{~km}$ NE of Morávka village, SW edge of Velký Lipový settlement, right tributary of Velký Lipový stream, $550 \mathrm{~m}$ a.s.1., bark of Malus sp. \& Acer platanoides, leg. Nociarová 25.VII.2006, det. Plášek (OP).

\section{Pustevny}

Between Pustevny settlement \& Čertův Mlýn Mt, 960 m E of Pustevny settlement, 941 m a.s.l., bark of Salix caprea, leg. Štefúnová 16.IX.2007, det. Plášek (OP).

$490 \mathrm{~m} \mathrm{~S}$ of Pustevny settlement, along a public road, 996 m a.s.1., bark of Salix caprea, leg. Štefúnová 16.IX.2007, det. Plášek (OP).

\section{Ostravice}

Ostravice village, loc. "Butořanka", 750 m a.s.1., bark of Acer pseudoplatanus, leg. Plášek 24.V.2000 (OP).

\section{Zygodon rupestris Schimp. ex Lorentz}

\section{Nýdek}

Nýdek village, near a chaple, 405 m a.s.l., bark of Acer sp., leg. Plášek 18.10.1999 (OP). 
Salajka

$380 \mathrm{~m}$ ENE of Bumbálka border settlement, Salajka reserve, $800 \mathrm{~m}$ a.s.l., bark of Fagus sylvatica, leg. Plášek 9.XII.2006 (OP).

\section{Discussion}

Total 16 species from the family Orthotrichaceae were recently recorded on the study area.

Among the most interesting findings belongs an occurrence of Zygodon rupetris, which is considered as an endangered species bryoflory Czech Republic (Kučera \& Váňa 2005). The species was in the past recorded only once in the Moravskoslezské Beskydy Mts. It was found by Pospíšil in 1960 near Valašská Bystřice town (Vondráček 1994). The specimen is housed in BRNM. Recently the species was collected only on two new localities, which unfortunately confirms that the species is still very rare on the study area.

Orthotrichum patens, was recently found only one time in the study area. The taxa is included in category of vulnerable species (Kučera \& Váňa 2005). But recently it is found more often throughout the all territory of the Czech Republic and obviously it should be moved into "least concern" taxa.

The all moss species were collected randomly from whole spectrum of trees growing in the study area. Nevertheless, the mosses showed significantly closer host specificity for Malus domestica (17.1\% findings), Fraxinus excelsior (13.4 \% findings), Salix caprea (11.7\% findings) or Acer pseudoplatanus (11.1\% findings). On the contrary, they were observed very rarely on bark of Picea abies, Abies alba, Swida sanguinea, Quercus robur.

An unusual phenomenon is occurrence of gemmae in Orthotrichum pallens. Producing of gemmae as the vegetative propagules is well known in some taxa within Orthotrichum genus (cf. Lewinsky-Haapassari 1995, Nyholm 1998, Vondráček 1993). But there isn't any known literature information about observing of the moss Orthotrichum pallens with created vegetative propagules. Author recently found the gemmiferous plants growing on bark of Alnus incana near Staré Hamry settlement.

Finally, it should be noted the newly described moss species, Orthotrichum moravicum, which was found in July 2006 in the Moravskoslezské Beskydy Mts (Plášek et al. 2009), and is therefore included in the list above.

Acknowledgements: The field survey was supported by the grant IGS201104 of Silesian Museum in Opava.

\section{References}

Kučera J. \& Váňa J. (2005): Seznam a červený seznam mechorostů České republiky (2005). - Př́roda 23: 1104.

Lewinsky - Haapassari , J. (1995): Illustrierter Bestimmungsschüssel zu den europäischen OrthotrichumArten. - Meylania. 9:1-57

Nyholm , E. (1998): Orthotrichum. In: Illustrated Flora of Nordic Mosses. Fasc.4. Nordic Bryological Society. 377-401.

Plášek V., Sawicki, J., Trávníčková, V. \& Pasečná, M. (2009): Orthotrichum moravicum (Orthotrichaceae), a New Moss from the Czech Republic. - Bryologist, 112: 329-36.

Vondráček, M. (1993): Revize a rozšíření druhů rodu Orthotrichum Hedw. v České a Slovenské republice. Sborn. Západočes. Muz., Plzeň, Přír. 85:1-76.

- (1994): Revize a rozšíření druhů rodů Ulota Brid. a Zygodon Hook. et Tayl v České a Slovenské republice (Orthotrichaceae - Musci). - Sborník Západočeského muzea v Plzni, 26 pp.

Author's address: Vítězslav Plášek, Dept. of Biology and Ecology, Faculty of Science, University of Ostrava, Chittussiho 10, CZ-710 00 Ostrava, Czech Republic, e-mail: vitezslav.plasek@osu.cz 